\title{
Choosing Nursing as a Profession
}

1 Kristina Kolar*

${ }^{1}$ Danijel Mijatović ${ }^{*}$

1 Mateja Todorovski*

1 Janko Babić

1 University of Applied Health Sciences in Zagreb

* Undergraduate nursing students at University of Applied Health Sciences in Zagreb

Article received: 20.02.2018.

Article accepted: 06.06.2018.

Author for correspondence:

Danijel Mijatović

Address: Rade Končara 7a, 44000 Sisak

Phone: 098/974-8000

E-mail: danijel.mijatovic55@gmail.com

DOI: $10.24141 / 2 / 2 / 1 / 5$

Keywords: nursing, profession, reasons of choice, study satisfaction

\section{Abstract}

The aim of the research was to determine the reasons why students enroll in undergraduate nursing studies and in what way the students' age, type of studies and familiarity with the profession affect their selection.

In total, 156 first- and second-year nursing students between the ages of 18-30 participated in the study that was carried out at the University of Applied Health Sciences in Zagreb. The students had to answer multiple choice questions about their personal reasons for choosing nursing studies and were offered four different reasons as possible answers.

Most students chose idealism as the reason for choosing nursing studies (46.2\%), regardless of whether they were full-time or part-time students. Students who had not attended a secondary nursing school mainly choose materialism as the reason (20.0\%). Furthermore, the choice of idealism decreases with the students who had already attended a different university (34.8\%), while for the first-time students the choice of the same reason increases (48.1\%).

For almost half of the interviewed students, humanity, ethics, and the desire to help are the reasons why they chose nursing studies, while $30.8 \%$ of the interviewed students selected materialism as the main reason. It is interesting that regardless of the type of reason the students chose, $95.5 \%$ concluded that they still want to work in the nursing profession in the future. Only a handful of students opted not to 
choose any of the given answers, but chose to describe their own reason themselves. It is pointed out that only one student responded to the question by saying, "Because I felt the calling."

The research was based on four reasons for choosing nursing as a profession: idealism, materialism, heritage, and choosing it as their second choice. In the fifth question they had to choose one of the following reasons: idealism, materialism, heritage, or second choice. They were given the definition of every option to make sure that they would choose the right one, based on their subjective understanding of nursing as a profession.

\section{Introduction}

"The mission of nursing in the society is to help individuals, families and groups in the surrounding they live in, identify and fulfill their physical, mental and social needs. Nurses are expected to develop and perform actions that promote and maintain health, as well as prevent the development of illness. Nursing also includes planning and providing care during an illness and the recovery process, and it also encompasses physical, mental, and social views of everyday life, corresponding to the degree in which they affect health, illnesses, disabilities and death" (1). From the past until today nursing has been considered as one of the helping professions. It is a service essential to the well-being of people. Helping others to achieve the highest level of well-being is the aim of nursing and one of the basic components of professional nursing (2).

Nursing students in Croatia have about 20 courses a year in which they learn about their profession and they also increase their knowledge in hospitals. They are taught how to be humane, ethical, skillful, resourceful, calm, professional, collegial and compassionate. But what made them choose nursing studies? How long do they think about it before they choose such a profession? Decisions about jobs and careers are made at an early age. By the time students enter middle and high school they already have rejected most jobs on the basis of perceptions. The majority of students don't reject nursing, they simply do not give nursing any consideration (Foskett \& HemsleyBrown, 1998; Hemsley-Brown \& Foskett,1999). Over $33 \%$ of those who choose nursing as a career do so early in life (Fuchs \& Ehrenfelf, 1994). They make the decision based on stereotyped and idealized images and without a thorough knowledge of the opportunities (3).

According to a research that was carried out in the USA, most associated degree students and master students made their decision in junior high and high school, and most bachelor students made their decisions in high school or the first two years of university education. The same research also shows that students chose one of the options as the reason for choosing nursing studies as their profession. The majority of the students $(71.71 \%)$ said their reason was a past experience with a loved one or their own experience in a hospital. $65.6 \%$ of them had already worked in health care, $65.3 \%$ of them said they have a family member or a friend who is a nurse, $53.5 \%$ have a role model who is a nurse, and $21.6 \%$ of them chose nursing studies because of the good portrayal of the profession in the media (6).

According to a study among students at secondary schools of nursing and general grammar schools about their interest in continuing their education in the nursing profession, which was published in 2012 in the journal Sestrinski glasnik (The Nursing Journal), there is the so-called "critical mass" of students interested in nursing studies. The results of this study show that nursing studies are in the first place of desired universities among students at secondary schools of nursing $(35.13 \%)$, while students who attend general grammar schools are more interested in philosophy, economics, law, medicine, and pedagogy (4).

Each year, different universities invite future students to choose their programs. They do that in an exciting and accessible way, and that is exactly how they do it at the Universities of Applied Health Sciences.

Nowadays there is a plethora of reasons why young people choose nursing studies after finishing secondary school. Nursing is for many a humane profession, through which they can show good character traits, hard-working qualities, and the wish to help others. Many also consider nursing to be a way of improving themselves to become people who can serve as examples to others. Some see nursing as a great opportunity to earn money, seeing that it stands for a really sought-after profession. 
"Students' Perceptions of Ideal and Nursing Career Choices" is a study that deals with that topic. The participants of that study had to answer the question "What does nursing mean to you?" and the five most frequent responses were: caring, personal growth, illness focus, professionalism and job security (5).

On the other hand, many people have relatives who work in this profession. They consider them to be their role models and the reason why they want to do this exact job.

Williams Wertenberger and Gushuliak in their study of 626 Canadian students reported that job opportunity/security was the primary reason students choose nursing as a career followed by helping others and working with people. Several students considered nursing a calling, a ministry, or God's will for their lives, evidencing the religious theme (6). For others, nursing had been a childhood dream and something that had always been one of their interests (6). Other students valued the variety, flexibility, and opportunities offered by nursing, including graduate school and travel (6). One student in this study said: "Other graduates come out of university and it might take a while to find a job, but with nursing you are guaranteed a job straight away due to shortage of nurses in Ireland and you can travel as well," which also proves that students choose nursing because they consider it to be easy to find a job in this field.

It is striking that students prefer this profession for reasons such as having a nurse/nurses among their family members (more than half of the students) and the possibility of finding job. This finding could be the sign which shows that students choose this profession not because they are interested in it or have tendency towards it but because this profession is an ideal opportunity of employment and the students are under the influence of their families (2).

There are many reasons, but one wonders about the most popular reason for choosing nursing studies at Croatian universities. The answers to that question give a clear insight into the quantitative and qualitative state of the student education process as well as into the steps that future academics need to take in order to improve the education and the progress of nursing as a profession. Furthermore, the purpose of this study was to get the results that show to what extent is idealism present in the choice-making process, seeing that one tends to strive for idealism as a factor that influences the systematic quality and proper interest of students, which depends on the number of academics who actually continue working in their profession. Authors Ljubotina and Krznarić conducted a study which tells us that students mostly name the interest in the field they study (64.8\%) as the reason why they chose their current studies. Other reasons are the success in secondary school subjects which are connected to that specific field $(11.2 \%)$ and the prospects of finding a job in their profession $(9.8 \%)$, while $11.5 \%$ of the participants claimed that they did not have a specific reason (7). Our study was conducted at the University of Applied Health Sciences in Zagreb, the oldest establishment for higher education of nurses in Croatia, with the biggest number of students in this profession.

The aim of the research was to determine the reasons why students enroll in undergraduate nursing studies and in what way the students' age, type of studies and familiarity with the profession affect their selection.

\section{Methods}

This study included an anonymous questionnaire designed by the authors. The questionnaire consisted of six multiple-choice questions or questions which required the participants to write their own answer. The sample consisted of 156 first- and second-year undergraduate students at the University of Applied Health Sciences in Zagreb, aged 18-30.

The questionnaire consists of two parts. The first part includes general information about the students. All students had to enter their age first. Then they had to state if they are a full-time or part-time nursing student, considering that there are both full-time and part-time nursing students at the University of Applied Health Sciences in Zagreb. Furthermore, nursing students come from different educational backgrounds. Some students went to secondary schools of nursing, while others went to different secondary schools, such as secondary schools of economics, general grammar schools, secondary veterinarian schools, etc. To see if secondary education would have an impact on the results of the study, the participants had to answer the third question: "Did you attend a secondary school of nursing?". The fourth 
question was about whether students had studied something else before this, to see if this university was their first choice or if it was a replacement for another university which they did not finish.

In the second part of the questionnaire, the students had to choose between four reasons for choosing nursing studies. The study was based on four methods of choosing nursing as a profession: idealism, materialism, heritage, and choosing it as a second choice. In the fifth question they had to choose one of the following reasons: idealism, materialism, heritage, or second choice. They were given the definition of every option to make sure that they would choose the right one, based on their subjective understanding of nursing as a profession. These were the descriptions of the reasons:

- MATERIALISM - I chose nursing studies because it is in-demand. I am almost entirely sure that I will find a job after I finish my education.

- HERITAGE - Mothers, fathers, sisters or brothers are the ones who pointed me in this direction, because they also work in health care. My parents have a private practice, so I chose nursing studies in order to be able to work there.

- IDEALISM - I am a dreamer and an idealist when it comes to the nursing profession. I think nursing is a humane and ethical profession. I chose nursing because I have a strong desire to help others. The picture showing Florence Nightingale visiting wounded soldiers at night to make sure they are well shows me how a nurse should behave.

- SECOND CHOICE - *I was not able to get into the School of Medicine, so I chose nursing studies. * first studied something that is not connected to health care, but then I transferred to nursing. *This is the only university I got into.

The final question dealt with the fact whether they wanted to pursue a job in this field in the future, to see how satisfied students are with the studies they have chosen.

\section{Ethics}

The procedures that were followed were in accordance with the ethical standards of the responsible institutional committee on human experimentation and with the Helsinki Declaration and Uniform Requirements for Manuscripts submitted to Biomedical journals.

\section{Results}

There were 68 (43.6\%) first-year students and 88 (56.4\%) second-year students. The sample consisted of $136(87.2 \%)$ full-time and $20(12.8 \%)$ part-time students. Based on all 156 participants choosing their reasons, we got the following results: 72 students $(46.2 \%)$ chose idealism, 48 students (30.8\%) chose materialism, nine students $(8.8 \%)$ chose heritage, and for 27 students (17.2\%) nursing was a second choice (Chart 1).

In order to interpret the results differently and see the differences based on the different criteria in the questionnaire, the results were separated according to the following criteria: age, type of studies (fulltime and part-time students), previous (secondary) education, and education at a different university. For the analysis of differences based on the age of the participants, we divided them into groups younger and older than 21. Students younger than 21 chose the following answers: 39 students (48.2\%) chose idealism, 23 (28.4\%) chose materialism, four students (4.9\%) chose heritage, and 15 students $(18.5 \%)$ chose nursing studies as a second choice. There are a lot of similarities between those students and the group of students who are 21 or older. They provided the following answers: 33 students (44\%) chose idealism, 25 of them (33.3\%) chose materialism, five $(6.7 \%)$ chose heritage and 12 students said $(16 \%)$ that nursing was their second choice. There are small differences between the results for full-time and part-time students. Full-time students mostly chose idealism (66 of them, or $44.9 \%$ ), 43 full-time students (31.6\%) chose materialism, six of them $(4.4 \%)$ chose heritage and 26 students $(19.1 \%)$ chose nursing as their second option (Chart 2). 


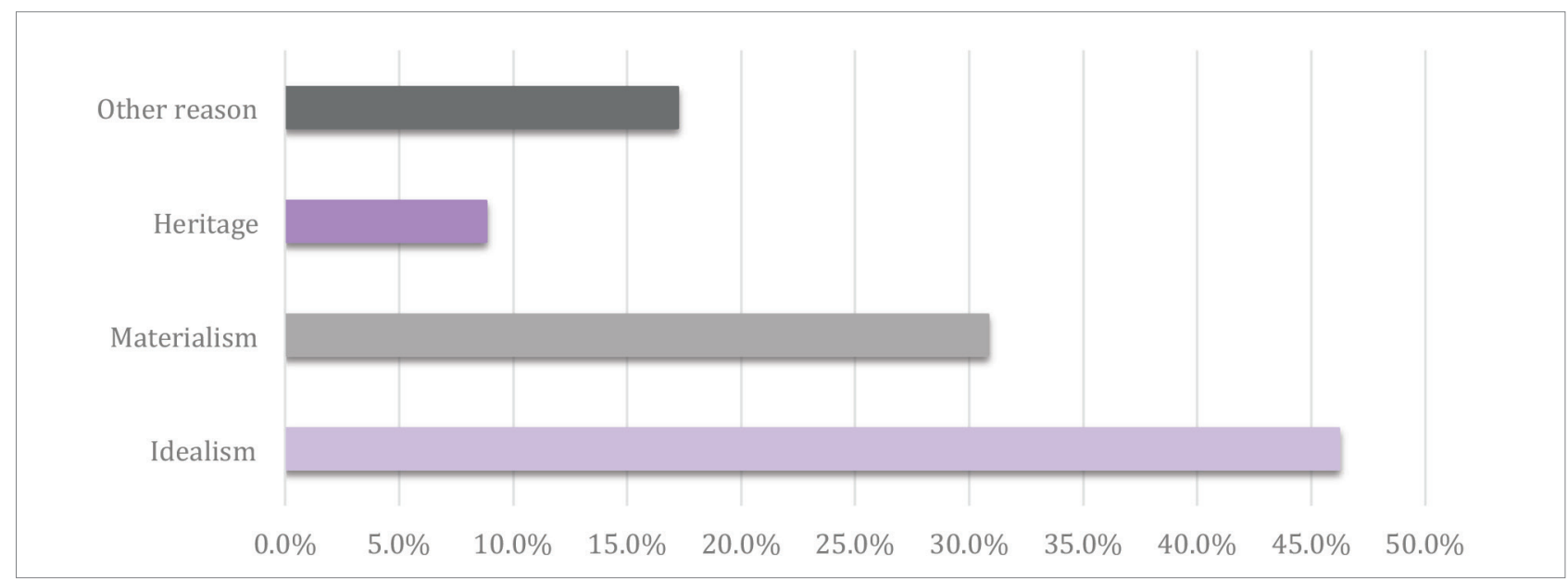

Chart 1. Results with all participants included

Eleven part-time students (55\%) chose idealism as their reason, five students (25\%) said it was materialism, three students (15\%) chose heritage and one student $(5 \%)$ chose nursing as the second option (Chart 3).

Out of all the participants, 71 of them (45.5\%) attended a secondary school of nursing, while 85 of them (54.5\%) went to a different type of secondary school. Students who went to a secondary school of nursing chose nursing studies mainly because of idealism (34 of them, or 47.9\%). Materialism was the main reason for 26 students (36.6\%), heritage for one student $(1.4 \%)$, and there were ten students $(14.1 \%)$ who had a different first choice. Students who did not go to a secondary school of nursing also mostly chose idealism - 38 of them (44.7\%). 22 students (25.9\%) chose materialism, eight of them (9.4\%) chose heritage, and for 17 students (20\%) who did not attend a secondary school of nursing, nursing studies were a second choice. There were 23 students $(14.7 \%)$ among the participants who had previously attended a different university, while 133 students (84.3\%) had not studied anything else before. Students who had previously studied something else opted for the following answers: eight of them chose idealism (34.8\%), seven (30.4\%) chose materialism, and heritage and second choice were each chosen by four students (17.4\%) (Chart 4).

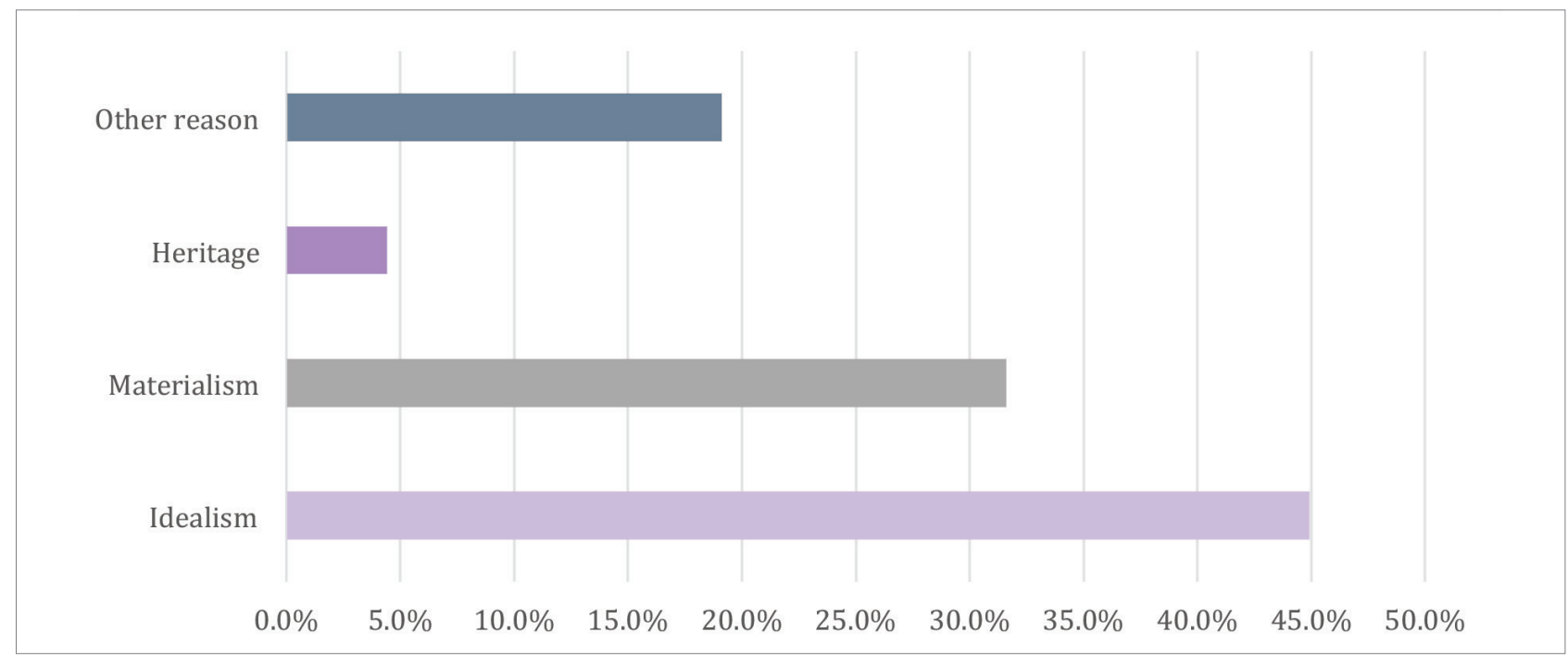

Chart 2. Results based on the type of studies - full-time students 


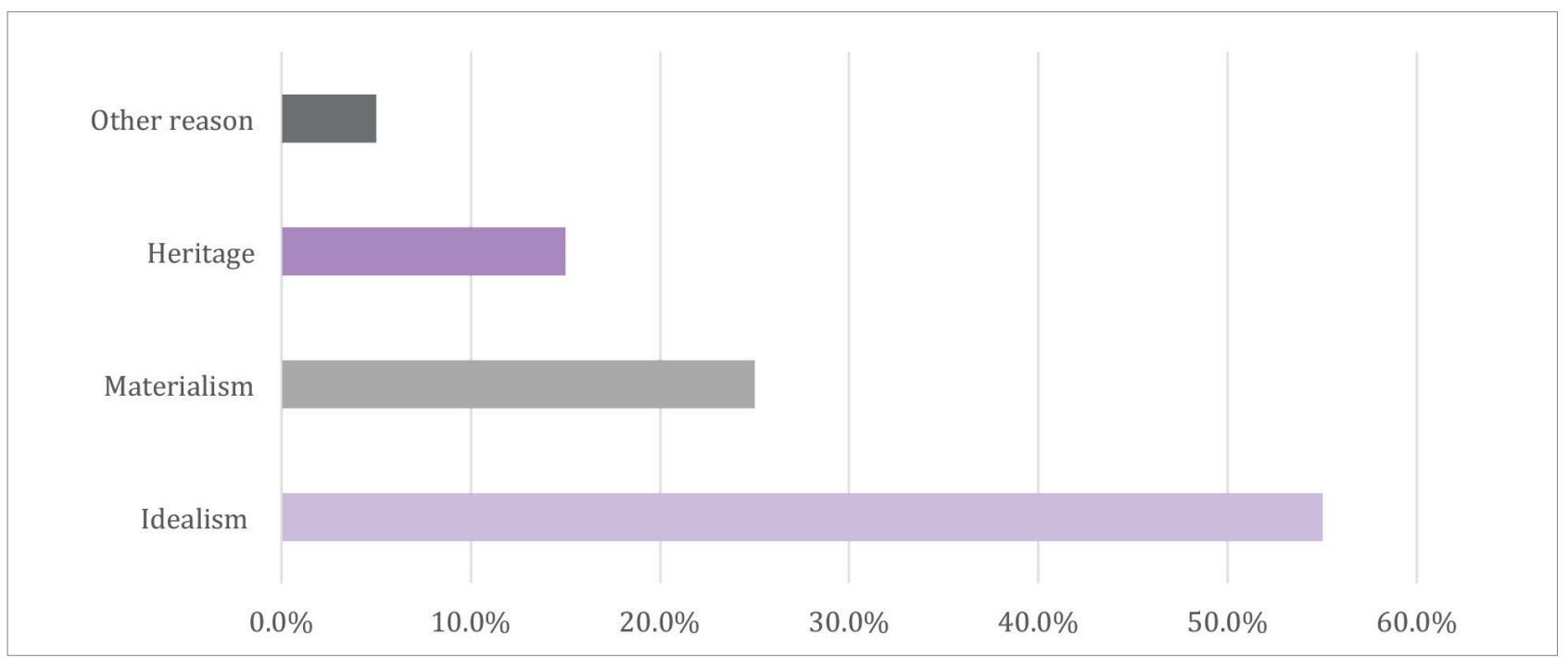

Chart 3. Results based on the type of studies - part-time students

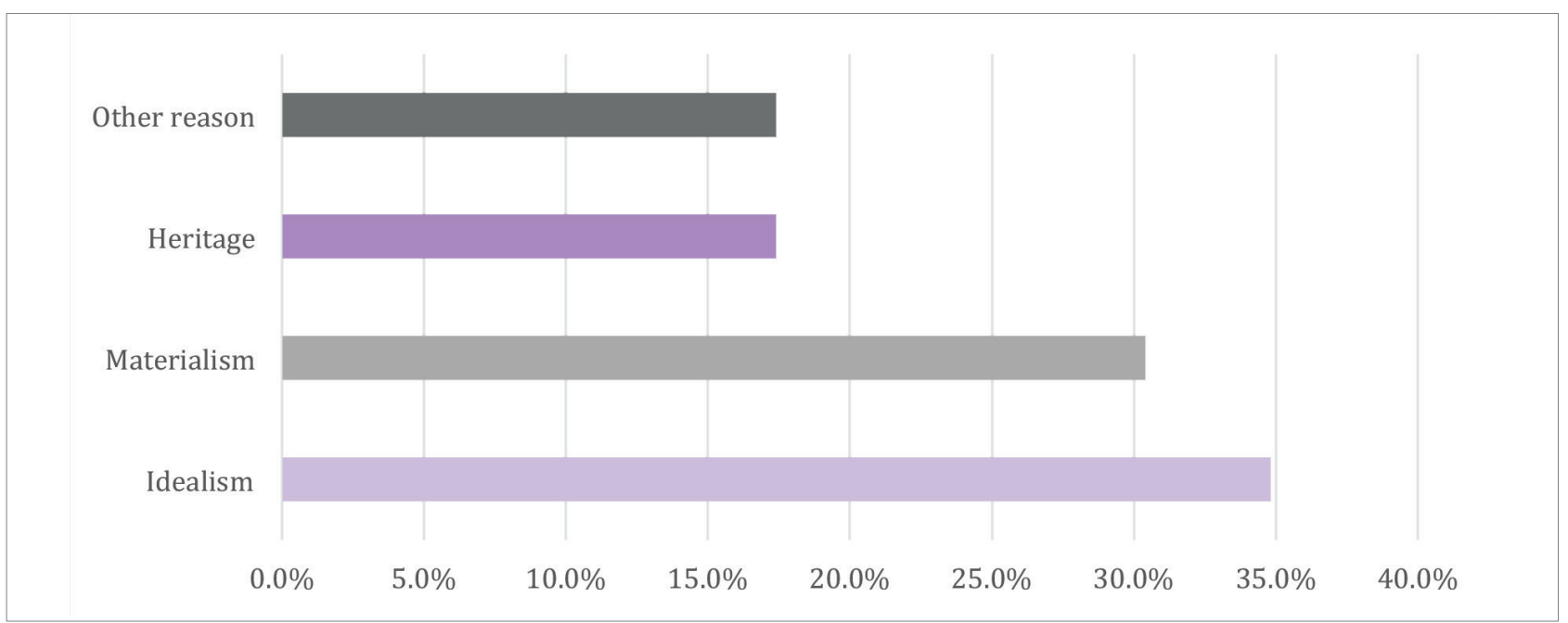

Chart 4. Results based on choosing nursing studies as the second option

Students who did not study anything before nursing mostly chose idealism (64 of them, or $48.1 \%$ ). Materialism was chosen by 41 students $(30.8 \%)$ and heritage by five of them (3.8\%) (Chart 5).

There were 23 participants (17.3\%) who chose nursing studies because they failed to get into their first choice university. Finally, the answers to the question if students want to pursue a job in this field show satisfying results. As many as 149 out of 156 students want a job in health care in the future, which is $95.5 \%$ of them, while seven students $(4.5 \%)$ want to enter a different profession after their studies.
The data was analyzed using a chi-squared test and there are no statistical differences in the reasons for choosing nursing with students who went to a secondary school of nursing and students who had a different secondary education (Table 1.). 


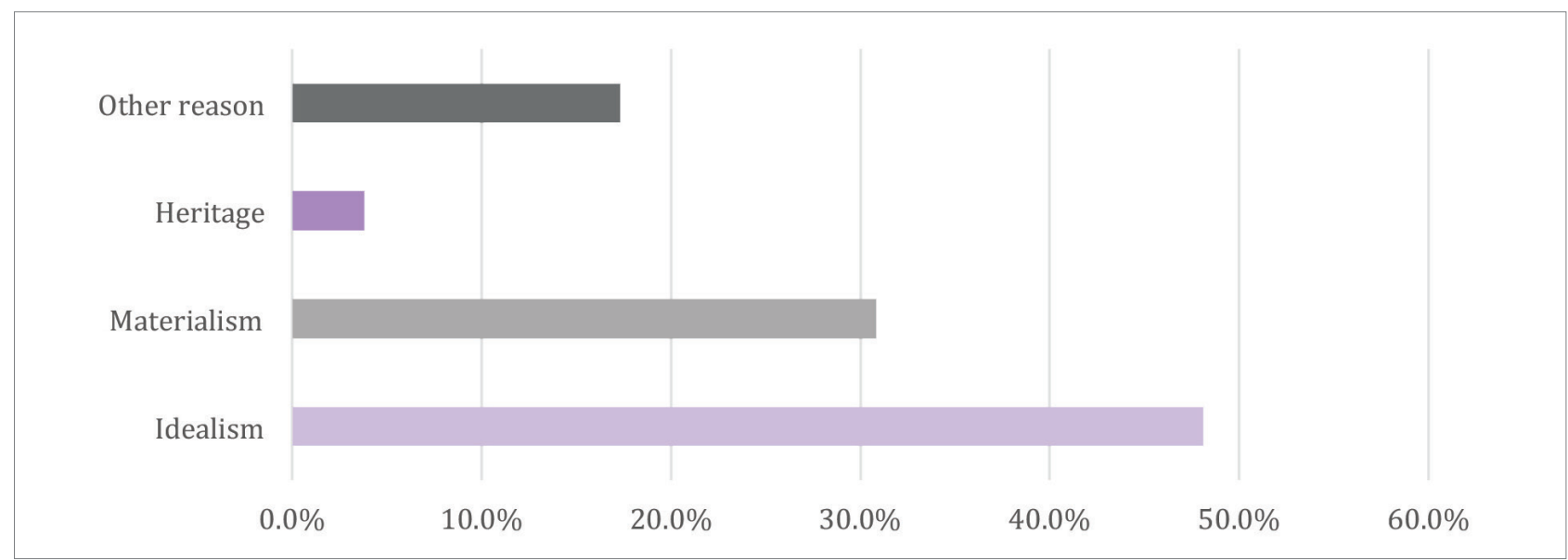

\section{Chart 5. Results based on choosing nursing studies as the first option}

\section{Other reason}
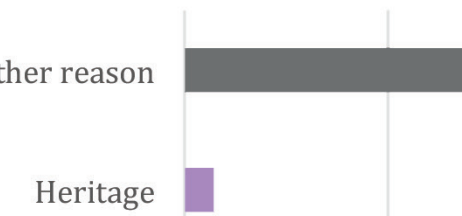

Idealism

$0.0 \%$

$10.0 \%$

$20.0 \%$

$30.0 \%$

$40.0 \%$

$50.0 \%$

$60.0 \%$

Chart 6. Results based on previous education - a completed secondary school of nursing

Other reason

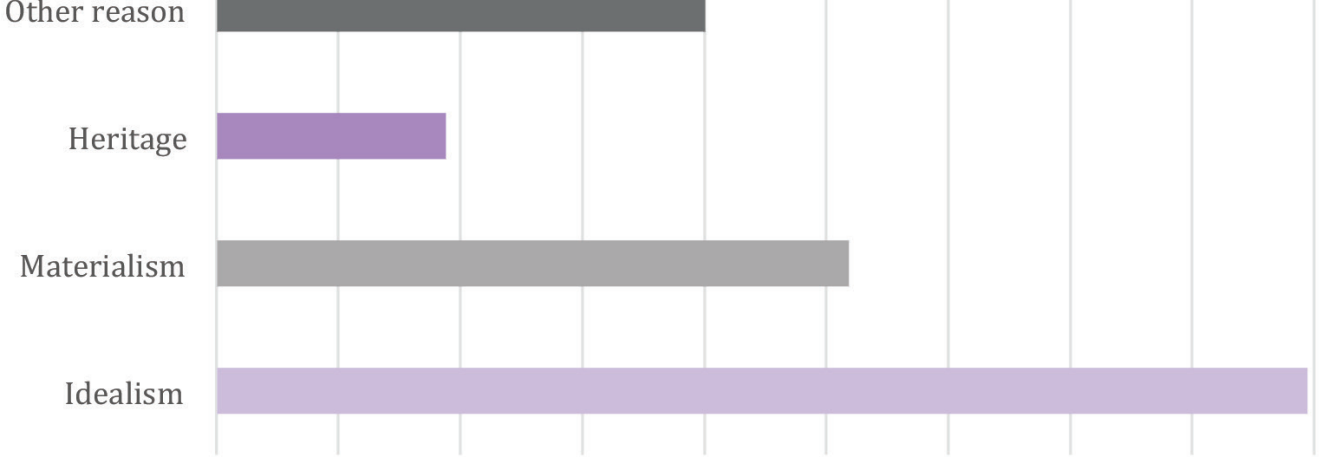
$0.0 \%$
$5.0 \% \quad 10.0 \%$
$15.0 \% \quad 20.0 \%$
$25.0 \% \quad 30.0 \%$
$35.0 \% \quad 40.0 \% \quad 45.0 \% \quad 50.0 \%$

Chart 7. Results based on previous education - a different secondary education (not a school of nursing) 


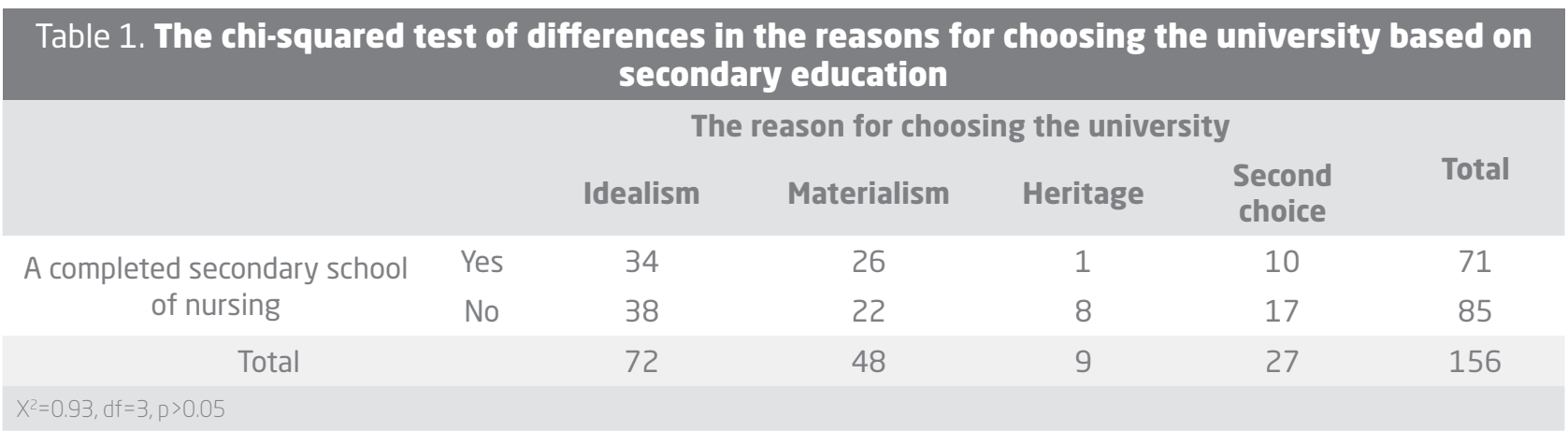

\section{Discussion}

The analysis of the results has shown that 72 out of 156 participants in this study chose idealism as their reason for choosing nursing studies. That means that $46.2 \%$ of them consider this profession to be a calling that includes humanity and taking care of the sick. According to literature, the tendency towards altruism lies behind the students' application for nursing studies and it is stated that people who have a high amount of tendency towards altruism choose the profession of nursing because they want to help people with deep affection.

The collected data also raises the question about the influence of materialism in the modern society and the influence of the financial portrayal of professions in the media on future students. There were as many as 48 students in this study who chose nursing as a profession due to financial security. They think that with a career in health care they will have a secure job and financial stability.

The problem of the education system at schools of nursing is accepting students who have not had any experience in hospitals as institutions in which they get acquainted with the

role of a health care worker, where they encounter the reality of life and death, and learn how to take care of others and interpret ethical and moral dilemmas.

Nursing is not seen as a high-status career focused on scientific knowledge and problem-solving skills but as a customary job that is characterized by powerlessness, passivity, weakness, lack of knowledge and independence, lack of a clearly defined career pathway, and inadequate long-term compensation (8).
Showing the younger generation that nurses are empowered to address global problems through modern technology, research, and informatics will be one way to let them see nursing is a career worthy of their consideration. Contracted images are those seen for oneself. Delegated images are those images passed on from parents and friends. Derived images are those from the media (8).

The study has shown that 48 students (30.8\%) chose nursing for financial reasons, financial stability and high chances of finding a job, both in Croatia and abroad.

In a research about the motivating factors in students' choice of nursing as a career, participants were asked what nursing means to them. Caring comments included responses such as helping, giving care and comfort, nurturance, serving, supporting, and sharing. Despite recent research indicating that students are more materialistic than in the past, results show that an overwhelming number continues to identify nursing as caring (9).

Our study encourages future students to apply a systematic and thorough process of choosing professions in health care, especially the nursing profession, where they will have to defend the patients' dignity, who will need their expertise and professionality. "Through education, students develop a professional identity, and their answers show the influence of education, especially when they are asked to describe a nurse's job or to name some stereotypes about the job. Some students show an idealistic way of thinking and there are no significant differences between students who went to a secondary school of nursing and those who went to other secondary schools" (10).

One of the disadvantages of this study is the fact that only 150 students participated, which is why it can- 
not show a real and all-encompassing state of all nursing students in the Republic of Croatia. Furthermore, the questionnaire used in this study gave the participants the option to choose only the most important reason for choosing nursing studies. It would have definitely yielded more detailed results if the participants had the option to choose more answers, which then would have been ranked by their popularity.

\section{Conclusion}

A study of the reasons for choosing nursing as a profession showed that the majority of the students choose it because of idealism. The analysis of the results showed that 72 out of 156 participants in this study chose idealism as their reason for choosing nursing studies. That means that a $46.2 \%$ of them consider this profession to be a calling that includes humanity and taking care of the sick. As opposed to idealism, materialism is present among a smaller number of students The study has shown that 48 students (30.8\%) chose nursing for financial reasons, financial stability and high chances of finding a job, both in Croatia and abroad. 17.2\% students chose nursing studies because they failed to get into their first choice university and $8.8 \%$ students chose heritage. Based on the data that was gathered, we can conclude that students who study at the University of Applied Health Sciences in Zagreb consider the nursing profession to be a humane calling and a job that gives them a chance to help other people every day. However, materialism was the second most popular reason for choosing nursing as a profession, which shows that money is also one of the criteria students consider when they choose their future profession.

\section{References}

1. Mojsović Z. i suradnici. Sestrinstvo u zajednici. Zagreb: Visoka zdravstvena škola. 2004.

2. Dal U, Arifoglu BC, Razi GS. What factors influence students in their choice of nursing in North Cyprus? Procedia Social and Behavioral Sciences 2009; 1: 1924-30.

3. Hoke JL. Promoting nursing as a career choice. Nurs Econ 2006; 24: 94-100.

4. Vičić Hudorović V, Rimac,B. Stupanj zainteresiranosti učenika srednjih škola za nastavak školovanja na Studijima sestrinstva. Sestrinski glasnik. 2012; 17: 94-99.

5. Tomey A. Schwier, B. Marticke, N. May, F. Student's Percetions Of Ideal And Nursing Career Choices. Nursing Outlook. 1996;1(44): 27-30.

6. Larsen PD, McGill JS, Palmer SJ. Factors Influencing Career Decisions: Perspectives of Nursing students in three types of programs. Journal of Nursing Education. 2003; 42 (4): 168-173.

7. Ljubotina D, Krznarić, T. Motivacija za studij I faktori uspjeha u studiju. Dani obrazovnih znanosti. Zagreb: Institut za društvena istraživanja: 2014; 45-49.

8. Hoke, Jl. Promoting Nursing as a Career Choice. Nursing Economics. 2006;2(24):94-100.

9. Kersten, J, Bakewell, K. Meyer, D. Motivating Factors in a Student's Choice of Nursing as a Career. Jurnal of Nursing Education. 1991; 1(30):30-33.

10. Čukljek, S. Smrekar, M. Ledinski Fičko, S. Konjevoda V. Razlike u percepciji sestrinstva između studenata sestrinstva i zaposlenih medicinskih sestara. JAHS 2015; 1(1): 35-42. 


\section{ODABIR SESTRINSTVA KAO PROFESIJE}

\section{Sažetak}

Cilj istraživanja bio je utvrditi koji su razlozi upisa studenata na sestrinske studije te koliko godine, vrsta studija i upoznatost sa strukom utječu na odabir.

Istraživanje je bilo provedeno na Zdravstvenom veleučilištu u Zagrebu na 156 studenata prve i druge godine studija u dobnoj skupini od 18 do 30 godina. Studenti su kroz anketu morali napisati osobni razlog odabira studija, a kako bi im olakšali odabir, autori su ponudili četiri razloga koji su opisivali mogućnosti odabira studija sestrinstva.

Najveći broj studenata odabralo je kao razlog idealizam (46,2\%), neovisno o tome jesu li studenti redovni ili izvanredni. Isto tako, studenti koji nisu pohađali srednju medicinsku školu većim postotkom odabrali su kao razlog drugi izbor (20,0\%). Za studente koji su prije studija sestrinstva već pohađali fakultet postotak odabira idealizma znatno se smanjuje (38,0 \%), dok se kod studenata koji prvi put pohađaju fakultet odabir istog razloga povećava (48,1 \%).

Gotovo polovica studenata odabire humanost, etičnost i želju za pomaganjem kao razlog odabira studija sestrinstva. Također, 30,8 \% ispitanika odabire materijalizam kao razlog upisa. Zanimljivo je kako, neovisno o razlogu koji su studenti odabrali, 95,5\% ih je zaključilo kako se i dalje želi baviti sestrinskom profesijom u budućnosti. Nekolicina studenata nije odabrala jedan od ponuđenih razloga, već su sami objasnili razlog odabira studija. Istaknuto je kako je samo jedna studentica odgovorila na anketu rečenicom „Jer sam osjetila poziv."
Istraživanje se temeljilo na četiri razloga za odabir sestrinstva kao profesije: idealizam, materijalizam, nasljeđe i drugi izbor. U petom pitanju morali su odabrati jedan od ponuđenih razloga. Ponuđen im je opis za svaki pojedini razlog kako bi mogli odabrati na temelju svojeg subjektivnog mišljenja zašto bi sestrinstvo bila profesija za njih.
Ključne riječi: sestrinstvo, profesija, razlozi odabira studija, zadovoljstvo studijem 